\title{
PENDAMPINGAN UMKM MENUJU DIGITALISASI MARKETING UPAYA KEBANGKITAN DI ERA NEW NORMAL
}

https://doi.org/10.33024/jkpm.v4i6.5293

\begin{abstract}
Albet Maydiantoro $^{1^{*}}$, M. Thoha B. Sampurna Jaya ${ }^{2}$, Widya Hestiningtyas ${ }^{3}$, Rahmawati $^{4}$
\end{abstract}

1,2,3,4Fakultas Keguruan dan Ilmu Pendidikan Universitas Lampung

Disubmit: 12 Oktober 2021 Diterima: 01 Desember 2021 Diterbitkan: 02 Desember 2021

Email Korespondensi: albet.maydiantoro@fkip.unila.ac.id

\begin{abstract}
ABSTRAK
Pelaksanaan Pengabdian Masyarakat dengan Judul Pendampingan UMKM Menuju Digitalisasi Marketing Upaya Kebangkitan di era new normal (Masyarakat Terdampak Tsunami Anak Gunung Krakatau) di desa Kunjir, Lampung Selatan mempunyai tujuan untuk meningkatkan kompetensi para pelaku UMKM di desa Kunjir Kabupaten Lampung Selatan dalam memanfaatkan teknologi untuk mengembangkan usaha yang mereka miliki agar operasi bisnis relevan dengan perkembangan zaman. Metode pengabdian masyarakat yang digunakan ialah dengan tahapan identifikasi awal (Fase Pra Pendampingan), kemudian dilanjutkan Fase pendampingan (pelatihan dan Pembimbingan) dan yang terakhir ialah Pasca Pendampingan. Berdasarkan pelaksanaan kegiatan pengabdian kepada masyarakat yang telah dilakukan diperoleh hasil bahwa terdapat peningkatan pengetahuan dan keterampilan pelaku UMKM tentang digitalisasi marketing. Kemudian diperoleh data akhir bahwa sebesar $87 \%$ pelaku UMKM di Desa Kunjir Kabupaten Lampung Selatan dapat membuat media pemasaran secara online melalui aplikasi Marketplace di Facebook, Shopee, Bukalapak, dan WhatsApp, namun terdapat $13 \%$ pelaku UMKM belum dapat membuat media pemasaran secara online.
\end{abstract}

Kata Kunci: UMKM; Digitalisasi; Marketing; Lampung Selatan

\begin{abstract}
Implementation of Community Service with the title MSME Assistance Towards Marketing Digitalization Awakening Efforts in the New Normal (Communities Affected by the Tsunami of the Children of Mount Krakatau) in Kunjir village, South Lampung has the aim of increasing the competence of MSME actors in Kunjir village, South Lampung regency in utilizing technology to develop the business they have so that business operations are relevant to the times. The community service method used is the initial identification stage (Pre Mentoring Phase), followed by the Mentoring Phase (training and Guidance), and the last is Post Mentoring. Based on the implementation of community service activities that have been carried out, the results show an increase in the knowledge and skills of MSME actors regarding the digitalization of marketing. Then the final data obtained that $87 \%$ of MSME actors in Kunjir Village, South Lampung Regency can create online marketing media through the Marketplace application on
\end{abstract}


Facebook, Shopee, Bukalapak, and WhatsApp, but there are 13\% of MSME actors who have not been able to create online marketing media.

Keywords: MSM; Digitalization; Marketing; South Lampung

\section{PENDAHULUAN}

Peristiwa dalam sejarah bencana alam di Indonesia pada tanggal 22 Desember 2018 yaitu terjadinya tsunami yang disebabkan oleh letusan Anak Gunung Krakatau di Selat Sunda menghantam daerah pesisir Banten dan Lampung. Dampak cukup parah terjadi di di kabupaten Lampung Selatan, yakni kecamatan Kalianda, kecamatan Rajabasa, kecamatan Sidomulyo, dan kecamatan Katibung.

Oleh karena itu, daerah yang terdampak tsunami ini harus segera dibangkitkan kembali terutama dalam hal perekonomiannya, utamanya dari aspek usaha. Sebab, bila tidak segera dibangkitkan, maka akan sulit keluar dari kondisi traumatik yang membekas di benak para korban, untuk pemulihan perekonomian di daerah bencana tsunami di Selat Sunda dan Lampung perlu keterlibatan berbagai instansi dalam memfasilitasi dan membantu para pelaku usaha kecil agar dapat kembali bangkit dan berkembang.

Pada saat ini para pelaku usaha di Kabupaten Lampung Selatan masih cenderung menggunakan media pemasaran yang bersifat konvensional. Media pemasaran dengan menggunakan media yang konvensional membutuhkan biaya dan waktu yang cukup tinggi, serta jangkauan pemasaran yang terbatas, karena untuk memasarkan ke daerah yang lebih jauh akan memakan biaya dan waktu. Sehingga membuat biaya produksi membengkak, namun jika pemasaran tidak dilakukan maka perkembangan usaha akan stagnan.

Pada umumnya mereka yang terlibat dalam sebuah usaha tentu menginginkan produknya laris manis atau laku terjual. Dalam hal ini usaha akan menghadapi persaingan yang ketat, sehingga perlu menerapkan strategi pemasaran yang tepat. Menurut Keller and Kotler (2012), Pemasaran merupakan suatu kegiatan yang bertujuan untuk menciptakan pasar bagi suatu produk (barang dan jasa). Strategi pemasaran atau bauran pemasaran meliputi 4 hal, yaitu: produk, harga, lokasi, promosi. Contoh strategi marketing secara konvensional yang telah diterapkan dari dulu hingga sekarang antara lain periklanan, pemasaran langsung, dan promosi penjualan. Ketiga contoh tersebut bukan berarti tidak lagi berguna saat ini, tetapi usaha harus benarbenar mempertimbangkan media pemasaran baru agar lebih efektif dan efisien.

Media secara digital kini menjadi media cukup penting yang digunakan di masyarakat. Menurut Nasir and Kusuma (2019), pengguna internet Indonesia menembus angka 132,7 juta orang dan menjadi negara kedua di dunia dalam hal penggunaan aplikasi Facebook. Di wilayah Asia, media digital bahkan telah menjadi gaya hidup modern, serta fakta sekarang menunjukkan penggunaan media digital telah membantu setiap orang melakukan rutinitas setiap harinya. Berbagai elemen masyarakat tidak pernah lepas dari aktivitas yang menggunakan media digital misalkan media digital yang digunakan saat ini seperti Facebook, Whatsapp, Instagram, masing-masing media digital tersebut memiliki fungsi yang sama yaitu untuk berkomunikasi dengan orang lain.

Mudahnya penggunaan media digital mendorong masyarakat atau pengusaha di seluruh dunia untuk memanfaatkannya dalam segala aktivitas. Media digital juga memiliki fungsi antara lain seperti branding, sharing, 
promotion dan marketing. Teknologi internet ini juga memiliki pengaruh yang menentukan pada perkembangan di bidang promosi produk (barang dan jasa) (Saputra et al., 2020).

Secara eksplisit, perkembangan media digital membawa peluang besar bagi berbagai sektor, termasuk UMKM. Terdapat 4 hal yang yang dapat dimaksimalkan dari adanya perkembangan media digital bagi dunia usaha yaitu (1) penelitian pemasaran; (2) komunikasi pemasaran; (3) promosi; dan (4) pemeliharaan customer relationship (Qonitat, 2020). Hal ini tentunya sangat menguntungkan bagi dunia pemasaran produk (barang dan jasa) karena kemudian terjadi peningkatan efisiensi dibandingkan dengan media kuno. Adanya perkembangan media digital memudahkan para pemilik usaha dalam memasarkan produk atau layanannya dengan biaya yang rendah dan efisien. Kenyataan bahwa pemasaraan digital tidak memiliki batas sebab pemilik usaha dapat menggunakan perangkat dan media digital apapun seperti smartphone, tablet, laptop, dan berbagai media sosial dengan konten berupa foto maupun video promosi. Menurut Yasmin et al. (2015) pemasaran dengan menggunakan media digital dianggap lebih berhasil menarik konsumen dibandingkan dengan pemasaran dengan cara konvensional. Meskipun begitu, keberhasilan pemasaran digital tidak dapat langsung berhasil, butuh usaha, strategi yang tepat, kemauan untuk berkembang dan inisiatif dalam menerapkan pemasaran digital.

Penguasaan media digital dalam pemasaran digital sangat dibutuhkan bagi para pelaku UMKM. Mereka setidaknya harus memahami bagaimana media digital bekerja dalam memasarkan produknya. Menurut Mardia et al. (2021) dalam pemasaran digital, para pelaku UMKM dapat melakukannya dengan cara membuat video produk mereka dan mempublikasikan secara rutin di media sosial, sering memposting dan mengupdate foto dengan menyertakan copywriting marketing yang menarik. Hal penting lainnya adalah mengajak konsumen dengan mengedukasi dan memperkenalkan kualitas produknya dengan menggunakan kata-kata kreatif, inovatif, menggairahkan untuk memiliki brand awareness produk UMKM dan mempengaruhi konsumen dalam mengambil keputusan pembeliannya. Namun demikian, media digital adalah tentang mendengarkan, berpartisipasi, dan berbagi. Menurut Taiminen and Karjaluoto (2015) sifat media digital yang dialogis tidak serta merta berarti bahwa pemilik usaha harus mempertahankan kehadirannya secara aktif di media tersebut. Namun, memahami bahwa sifat dialogis era digital akan membawa perubahan mendasar dalam praktik bisnis. Pelanggan berharap untuk didengar, didengarkan, dan diperhatikan, yang menantang UMKM untuk benar-benar berfokus pada pelanggan. Jika pelaku UMKM mampu memberikan pengalaman terbaik kepada pelanggannya, pelanggan tersebut kemungkinan besar akan menceritakan pengalaman mereka berurusan dengan perusahaan di web.

Kenyataan yang terjadi di lapangan bahwa para pelaku UMKM di Desa Kunjir masih belum memiliki kesadaran yang baik dalam memanfaatkan media digital sarana marketing dan mengembangkan kegiatan usahanya. Berdasarkan berbagai alasan yang telah dijelaskan di atas maka kami tertarik mendukung UMKM menuju digitalisasi upaya kebangkitan pemasaran di era new normal (masyarakat terdampak tsunami anak Gunung Krakatau) di Desa Kunjir, Lampung Selatan. 


\section{MASALAH}

Permasalahan mitra kegiatan pengabdian kepada masyarakat di daerah pesisir pantai ini adalah:

Sebagian besar UMKM di Lampung Selatan masih menggunakan pemasaran media konvensional yang membutuhkan biaya dan waktu yang tidak sedikit, serta jangkauan pasaran yang terbatas, karena untuk memasarkan ke daerah yang lebih jauh akan memakan biaya dan waktu lagi. Sehingga membuat biaya produksi membengkak, namun jika pemasaran tidak dilakukan maka perkembangan usaha akan stagnan. Oleh karena itu perlu adanya pemasaran online. Kurangnya pengetahuan sampai dengan adaptasi terhadap internet dan perkembangan teknologi yang dialami pelaku UMKM. Dalam pemasaran online peran sosial media sangat dibutuhkan, Sehingga dalam mengatasi permasalahan online yaitu dengan memanfaatkan sosial media. Pemasaran melalui sosial media tidak bisa instan, Butuh waktu yang cukup lama untuk bisa mendapatkan hasil. Mulai dari penjadwalan dan penerbitan banyak posting, mengelola dan terlibat dengan audiens potensial, menganalisa target audience, menemukan influencer dan menghasilkan prospek bisnis ke tim sukses pelanggan yang sangat efisien.

Pada umumnya pelaku usaha dalam menjalankan kegiatan usahanya tentu berkeinginan untuk membuat produknya laku terjual. Dalam hal ini, UMKM akan menghadapi persaingan yang ketat, sehingga perlu melakukan strategi pemasaran yang tepat. Menurut Kotler dan Keller (2012) Pemasaran merupakan kegiatan yang bertujuan untuk menciptakan pasar akan suatu produk. Strategi pemasaran atau bauran pemasaran (marketing mix) meliputi 4 hal, yaitu : Product, Price, Place, Promotion. Contoh strategi pemasaran konvensional yang diterapkan dari dulu hingga sekarang misalnya iklan, direct marketing, dan sales promotion. Ketiga contoh tersebut bukan berarti tidak bermanfaat lagi di masa sekarang, namun perusahaan tentunya perlu mempertimbangkan media baru dan strategi baru agar pemasaran menjadi lebih efektif dan efisien.

Masalah yang sampai saat ini masih perlu diperhatikan adalah kurangnya kesadaran masyarakat atau pengusaha untuk memanfaatkan media digital sebagai sarana untuk mengembangkan kegiatannya. Dengan produk yang relatif sudah cukup bagus, bila pasar yang dijangkau terbatas maka tidak akan cukup untuk menolong kelangsungan hidup perusahaan itu sendiri. Karena itu diperlukan langkah-langkah atau strategi mengatasi masalah pemasaran tersebut, salah satunya dengan memanfaatkan media digital. Dewasa ini sudah saatnya pelaku usaha mempersiapkan diri untuk memasuki era baru dalam dunia pemasaran. Sebab selama ini, kelemahan menentukan strategi pemasaran yang efektif dan efisien menjadi persoalan bagi hampir seluruh pelaku usaha di tanah air. Media digital kini menjadi media penting yang digunakan di setiap kalangan masyarakat. Menurut Widiarto (2016) penguna internet di Indonesia sebesar 132,7 juta jiwa dan menjadi Negara terbesar kedua dalam penggunaan aplikasi Facebook di dunia. Media digital tumbuh pesat seiring dengan bertambahnya pengguna internet di kawasan Asia Tenggara. Media digital pun bahkan sudah menjadi gaya hidup modern, di samping itu penggunaan media digital telah banyak membantu setiap orang dalam melakukan rutinitas. Individu, organisasi, bahkan pemerintahan juga tidak pernah terlepas dari aktifitas menggunakan media digital. Contoh media digital yang sering digunakan saat ini, yaitu: Facebook, Whatsapp, Instagram. Masing-masing media digital tersebut mempunyai fungsi yang sama, yaitu untuk berkomunikasi. 
Banyaknya kemudahan dan fungsi dari penggunaan media digital, mendorong masyarakat atau pengusaha di dunia, untuk memaalnfaatkan media digital tersebut pada setiap kegiatannya. Fungsi lain dari penggunaan media digital meliputi : branding, sharing, promosi, maupun marketing. Perkembangan teknologi informasi dan internet juga berpengaruh besar terhadap perkembangan di bidang promosi produk. Hal tersebut tentunya sangat menguntungkan bagi dunia promosi produk karena kemudian terjadi peningkatan efektivitas jika dibandingkan dengan media konvensional. Aspek utama yang mempengaruhi peningkatan efektivitas promosi produk melalui internet adalah media yang interaktif, bersifat fleksibel dengan pengertian adanya pertukaran pesan dua arah dan media yang responsif.

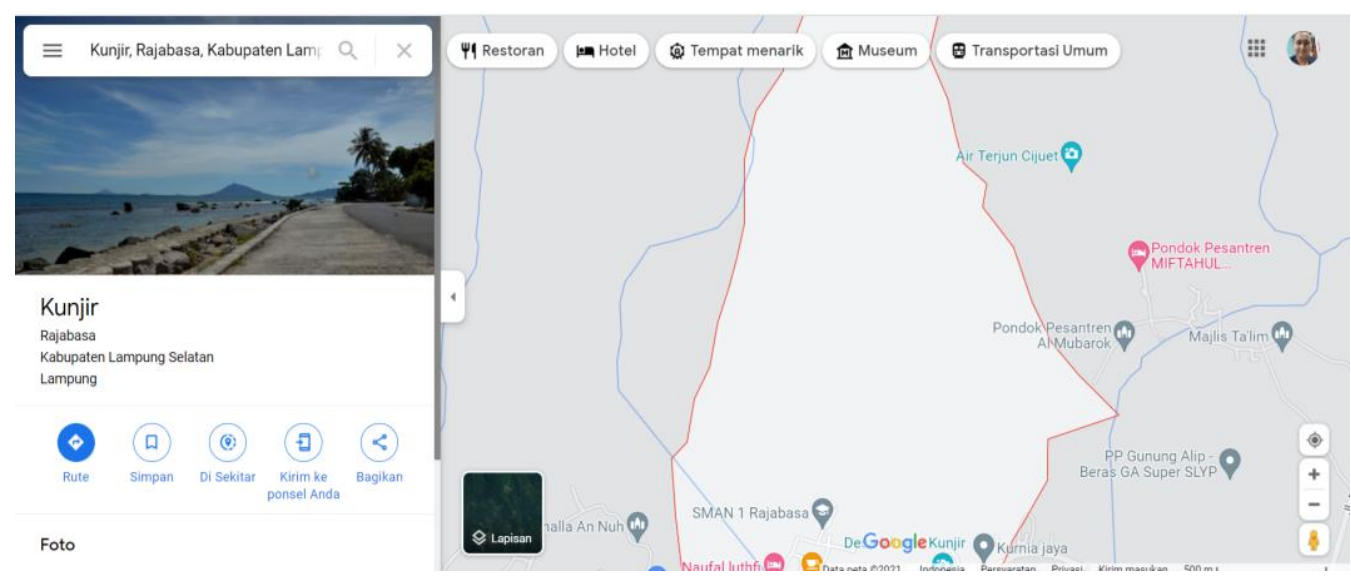

Gambar Peta Loaksi Kegiatan

\section{METODE}

Metode Pelaksanaan Pengabdian Kepada Masyarakat ini meliputi 4 tahap yaitu:

1. Identifikasi Masalah

Tahap ini merupakan tahap awal yang dilakukan dengan mencari sumber literature melalui wawancara langsung, survey lokasi dan mengkombinasikan dengan berita pada media lokal.

2. Pelaksanaan Pelatihan

Proses ini meliputi beberapa materi dan pelatihan. Pelatihan tersebut antara lain:

a) Pemberian materi pentingnya digital marketing dan memadukan dengan sumber yang ada.

b) Pemberian materi tentang konsep digital marketing

c) Memberikan pelatihan kepada umkm merancang digitalisasi marketing

d) Memberikan pelatihan kepada umkm dalam melaksanakan digitalisasi marketing

\section{Penerapan}

Kegiatan pada tahap ini ialah peserta setelah menerima pelatihan kemudian menerapkan dan mempraktikkan pada usahanya dengan membuat media digital sebagai promosi usaha.

\section{Evaluasi}

Tahap evaluasi merupakan tahap untuk mengetahui pengabdian yang telah dilakukan. Tahap ini meliputi pengukuran dengan beberapa instrument berikut: 
a) Test

Instrument test digunakan untuk melihat pengetahuan UMKM tentang pentingnya digital marketing dan konsep digitalisasi marketing

b) Protofolio

Instrument berupa portofolio digunakan untuk mengetahui kemampuan UMKM dalam membuat akun dalam aplikasi digital marketing, melaksanakan simulasi digital marketing, dan melakukan evaluasi akhir dengan observasi lapangan.

\section{HASIL DAN PEMBAHASAN}

Kegiatan dukungan UMKM menuju digitalisasi pemasaran merupakan upaya untuk menghadapi era new normal (masyarakat yang terkena dampak tsunami Anak Krakatau) di Desa Kunjir, Lampung Selatan, diikuti oleh 30 peserta dengan rincian sebagai berikut:

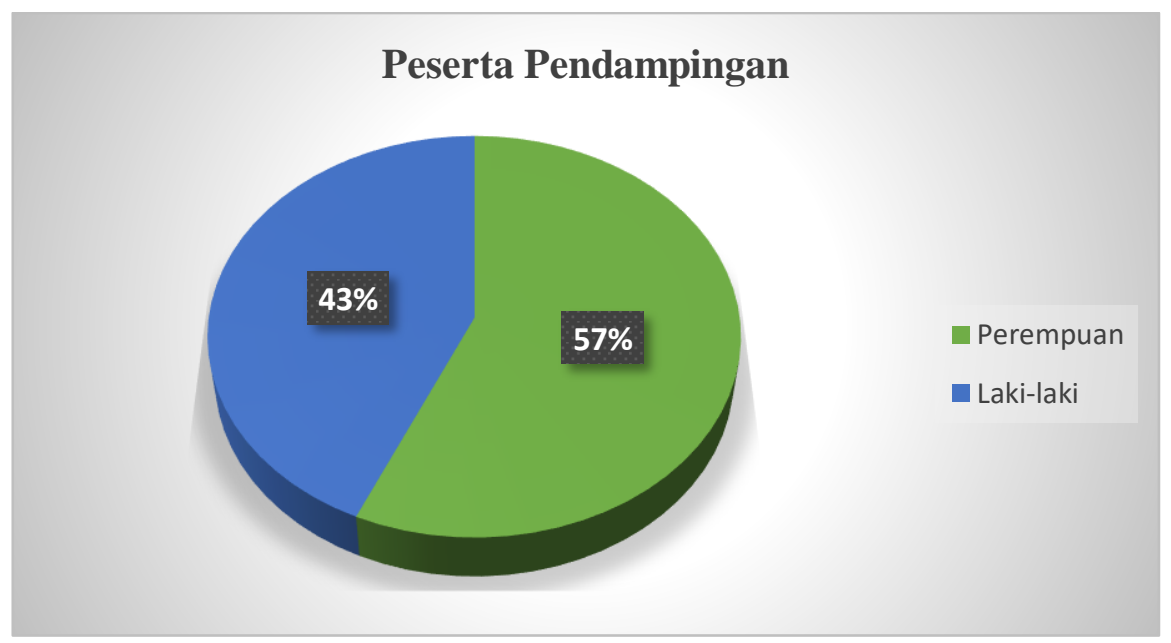

Gambar 1. Diagram peserta pendampingan

Peserta berdasarkan jenis kelamin terlihat bahwa peserta perempuan lebih banyak dibandingkan peserta laki-laki, Nampak pada gambar 1 peserta perempuan sebanyak $57 \%$ dan peserta laki-laki sebanyak $43 \%$.

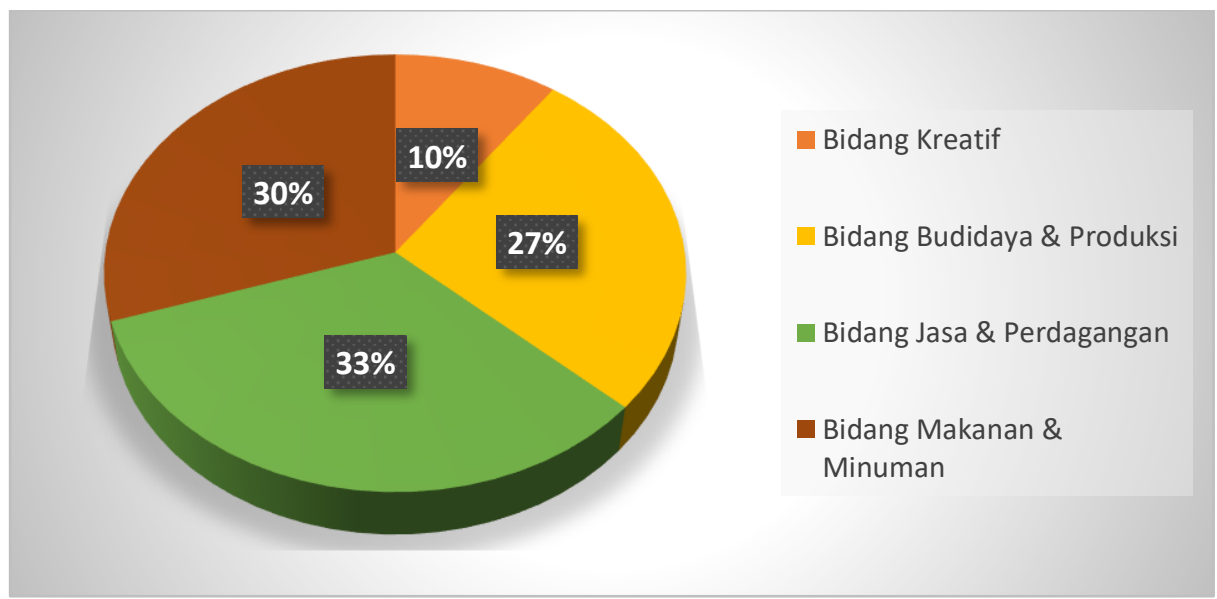

Gambar 2. Jenis usaha peserta PKM 
Berdasarkan gambar 2 terlihat bahwa Jenis usaha peserta pendampingan terbagi menjadi 4 jenis atau kategori, yaitu usaha bidang kreatif sebesar $10 \%$, bidang jasa dan perdagangan sebesar 33\% bidang makanan dan minuman sebesar 30\% bidang budidaya dan produksi sebesar 27\% Nampak jelas bahwa peserta dengan jenis usaha bidang jasa dan perdagangan paling banyak sehingga berbanding terbalik pada jenis usaha bidang kreatif.

Kegiatan pendampingan yang bertujuan agar pelaku UMKM mampu menggunakan fasilitas internet sebagai media pemasaran kepada konsumen sehingga akan mengefesiensi waktu, tenaga dan biaya dalam proses pemasaran dalam proses bisnis. Hal tersebut sejalan dengan pendapat bahwa internet harus digunakan sebagai sarana pemasaran dalam meningkatkan penghasilan usaha (Pradiani, 2017; Purwana et al., 2017; Vernia, 2017).

Berdasarkan hasil observasi selama proses pelatihan, peserta memiliki rasa ingin tahu yang besar terhadap pelatihan digital marketing. Apalagi pelatihan digital marketing seperti ini belum pernah diambil oleh para peserta pelatihan sehingga informasi yang disampaikan para pemateri benar-benar baru dan bermanfaat guna memberikan keuntungan bisnis di kemudian hari. Banyak daerah terdampak bencana alam lainnya yang belum tersentuh dengan pelatihan digital marketing (Arif, 2018), termasuk di desa kunjir Kabupaten Lampung Selatan.

Berdasarkan dampingan yang diberikan kepada peserta untuk digitalisasi pemasaran, upaya revitalisasi di era new normal pada masyarakat yang terkena dampak Tsunami Anak Gunung Krakatau, diperoleh hasil pemahaman materi awal peserta masih tergolong rendah. Dari jumlah peserta pelatihan yang terdiri dari pelaku UMKM sebanyak 30 orang hanya $24,5 \%$ yang mendapatkan nilai benar pada pretest dan $75,5 \%$ masih memiliki nilai rendah. Setelah mengikuti pelatihan jumlah peserta yang mendapatkan nilai baik saat posttest meningkat menjadi $86.4 \%$ sedangkan yang masih kurang baik hanya $13.4 \%$

Berdasarkan hal tersebut dapat diketahui adanya peningkatan pengetahuan tentang digital marketing bagi pelaku UMKM didaerah terdampak tsunami anak gunung krakatau. Hal tersebut dapat ditegaskan bahwa dalam nilai pretest pelatihan kecil dan setelah dilakukan pelatihan nilai posttest dapat meningkat (Darma et al., 2017; Marjana et al., 2014; Susantiningsih et al., 2018)

Menguasai keterampilan digitalisasi pemasaran merupakan upaya melahirkan kembali para pelaku usaha di era new normal. Berdasarkan dari penugasan tersebut dapat diketahui adanya peningkatan keterampilan digitalisasi marketing upaya kebangkitan di era new normal. Sebelum adanya pelatihan ini pemasaran masih menggunakan cara-cara konvensional. Melalui pelatihan ini para pelaku UMKM sudah dapat membuat digitalisasi marketing upaya kebangkitan di era new normal (Tayibnapis, 2021; Wijoyo, 2021).

Berikut beberapa dokumentasi pelaksanaan kegiatan pengabdian kepada masyarakat. 


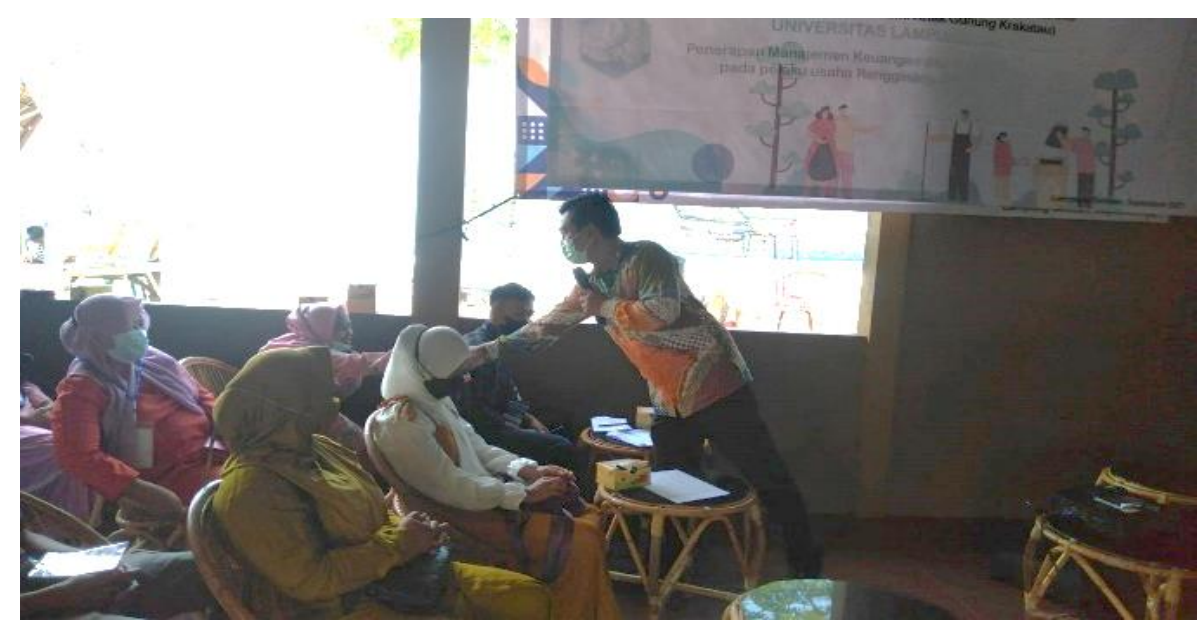

Gambar 3. Kegiatan PKM

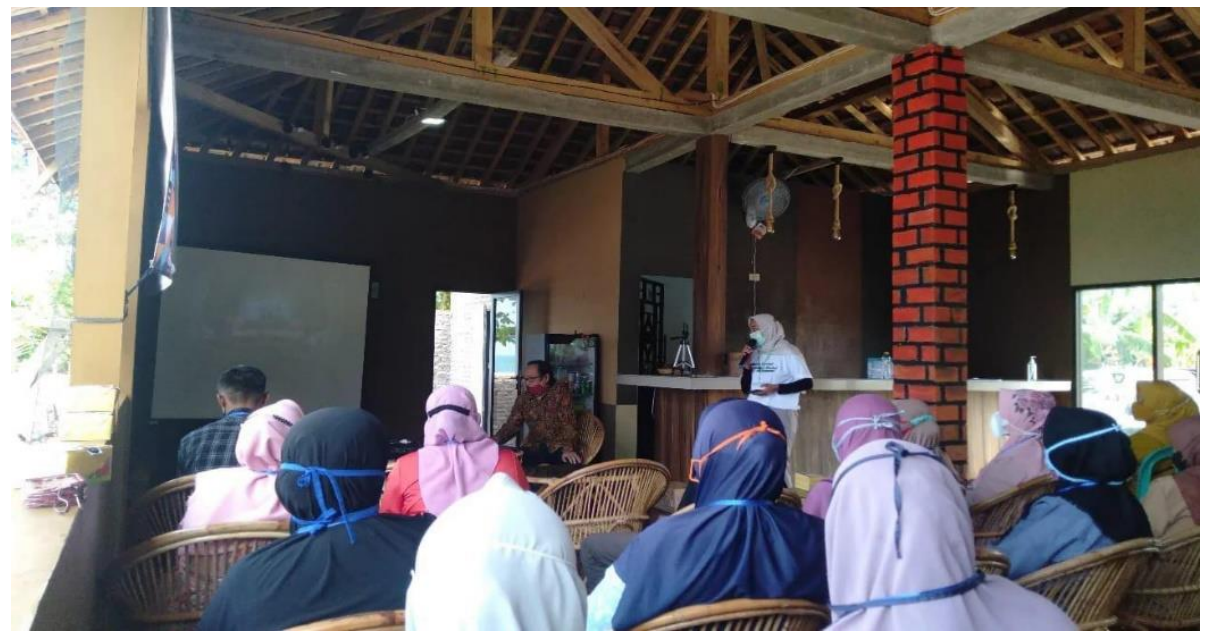

Gambar 4. Kegiatan PKM

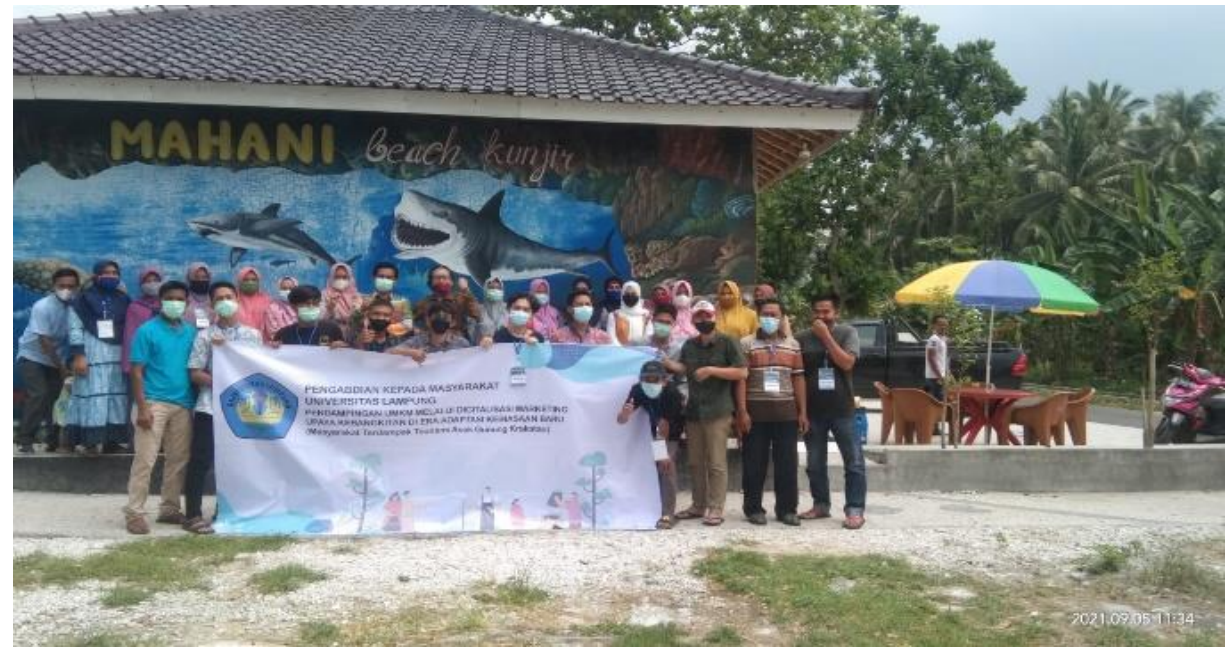

Gambar 5. Dokumentasi Peserta PKM 


\section{KESIMPULAN}

Berdasarkan hasil dari pelaksanaan pendampingan UMKM menuju digitalisasi marketing upaya kebangkitan di era new normal pada masyarakat terdampak tsunami anak gunung Krakatau di desa Kunjir, Lampung Selatan, maka dapat disimpulkan bahwa:

a. Pendampingan digitalisasi marketing upaya kebangkitan di era new normal pada masyarakat terdampak tsunami anak gunung Krakatau di desa Kunjir, Lampung Selatan sangat diperlukan. Karena pelaku UMKM merupakan bagian yang terdampak bencana alam.

b. Para pelaku UMKM yang terdampak tsunami anak gunung Krakatau di desa Kunjir, Lampung Selatan sangat antusias dan memperhatikan jalannya proses pendampingan termasuk pelatihan hingga akhir program selesai.

c. Kemampuan Pelaku UMKM telah meningkat tentang digital marketing sehingga akan meningkatkan pendapatan usaha para pelaku UMKM terdampak tsunami anak gunung Krakatau di desa Kunjir, Lampung Selatan.

d. Kegiatan pendampingan digitalisasi marketing upaya kebangkitan di era new normal di daerah terdampak tsunami anak gunung Krakatau di desa Kunjir, Lampung Selatan mudah dipahami oleh para UMKM. Hal tersebut dikarenakan pelatihan dilakukan dengan menampilkan contoh - contoh nyata dilanjutkan dengan diskusi dan Tanya jawab kemudian diakhir dilakukan pembimbingan dalam pembuatan akun umtuk digital marketing.

e. Kegiatan pendampingan telah menghasilkan 87\% pelaku UMKM untuk memasarkan produknya secara digital melalui marketplace facebook, shopee, bukalapak, tokopedia dan WhatsApp. Dengan menggunakan fasilitas internet sebagai media pemasaran kepada konsumen akan mengefesiensi waktu, tenaga dan biaya dalam proses pemasaran dalam proses bisnis,

\section{Saran}

Adapun saran yang dapat disampaikan ialah dalam melaksanakan kegiatan sejenis kedepan perlu menentukan wilayah sasaran yang membutuhkan sepertihalnya pelaksanaan PKM ini karena para pelaku sangat membutuhkan. Saran untuk pelaksanaan kegiatan sejenis ialah untuk selalu berkolaborasi antar berbagai pihak, baik perguruan tinggi, pihak desa/pemerintah setempat dan praktisi.

\section{Ucapan Terima Kasih}

Ucapan terimakasih kami sampaikan kepada para pelaku UMKM di Desa

Kunjir Kabupaten Lampung Selatan serta kepada Lembaga Penelitian dan Pengabdian Masyarakat (LPPM) Universitas Lampung.

\section{DAFTAR PUSTAKA}

Arif, A. (2018). Catatan Pemikiran dari Titik Nol Tsunami Aceh: Membangun Negeri Sadar Bencana. Syiah Kuala University Press.

Darma, K. A., Yoda, I. K., \& Sudarmada, I. N. (2017). Pengaruh Pelatihan Slalom Dribblingterhadap Kelincahan dan Vo2maks Siswa Peserta Ekstrakurikuler Sepak Bola. Jurnal IImu Keolahragaan Undiksha, 5(1), 1-11.

Keller, K. L., \& Kotler, P. (2012). Dirección de marketing. 
Mardia, M., Hutabarat, M. L. P., Simanjuntak, M., Sipayung, R., Saragih, L., Simarmata, H. M. P., Sulasih, S., Tanjung, R., Irdawati, I., \& Tjahjana, D. (2021). Strategi Pemasaran. Yayasan Kita Menulis.

Marjana, W., Sudiana, I. K., \& Budiawan, M. (2014). Pengaruh Pelatihan Shuttle Run Terhadap Kecepatan dan Kelincahan. Jurnal IImu Keolahragaan Undiksha, 2(1).

Nasir, M., \& Kusuma, A. H. P. (2019). Kegiatan E-Marketing Sebagai Bentuk Kewiraushaan Dini Bagi Pelajar. Celebes Abdimas: Jurnal Pengabdian Kepada Masyarakat, 1(1), 01-08.

Pradiani, T. (2017). Pengaruh sistem pemasaran digital marketing terhadap peningkatan volume penjualan hasil industri rumahan. Jurnal Ilmiah Bisnis Dan Ekonomi Asia, 11(2), 46-53.

Purwana, D., Rahmi, R., \& Aditya, S. (2017). Pemanfaatan Digital Marketing Bagi Usaha Mikro, Kecil, Dan Menengah (UMKM) Di Kelurahan Malaka Sari, Duren Sawit. Jurnal Pemberdayaan Masyarakat Madani, 1(1), 117.

Qonitat, I. (2020). Strategi Penggunaan Media Digital dalam Promosi Kerajinan Parang Sumbawa (Studi Kasus Komunitas Pandai Besi Desa Leseng, Kecamatan Moyo Hulu). Jurnal Tambora, 4(3), 51-57.

Saputra, D. H., Sutiksno, D. U., Kusuma, A. H. P., Romindo, R., Wahyuni, D., Purnomo, A., \& Simarmata, J. (2020). Digital Marketing: Komunikasi Bisnis Menjadi Lebih Mudah. Yayasan Kita Menulis.

Susantiningsih, T., Yuliyanti, R., Simanjuntak, K., \& Arfiyanti, A. (2018). PKM Pelatihan Mencuci Tangan Menggunakan Sabun Sebagai Perilaku Hidup Bersih Dan Sehat Untuk Masyarakat Rt 007/Rw 007 Desa Pangkalan Jati, Kecamatan Cinere Kota Depok. Jurnal Bakti Masyarakat Indonesia, $1(2)$.

Taiminen, H. M., \& Karjaluoto, H. (2015). The usage of digital marketing channels in SMEs. Journal of Small Business Enterprise Development.

Tayibnapis, A. Z. (2021). Studi Kasus Kebangkitan UMKM Di Indonesia.

Vernia, D. M. (2017). Optimalisasi Media Sosial Sebagai Sarana Promosi Bisnis Online Bagi Ibu Rumah Tangga Untuk Meningkatkan Perekonomian Keluarga. UTILITY: Jurnal Ilmiah Pendidikan Dan Ekonomi, 1(2), 105118.

Wijoyo, H. (2021). Strategi Pemasaran UMKM di masa pandemi. Insan Cendekia Mandiri.

Yasmin, A., Tasneem, S., \& Fatema, K. (2015). Effectiveness of digital marketing in the challenging age: An empirical study. International Journal of Management Science Business Administration, 1(5), 69-80. 